\title{
BIOACTIVE COMPOUNDS AND MINERAL COMPOSITON OF THE AQUEOUS EXTRACT FROM WILD CYCLAMEN (Cyclamen purpurascens Mill.) TUBERS
}

Ljiljana Stanojević*, Dragan Cvetković, Saša Savić, Sanja Petrović, Milorad Cakić

University of Niš, Faculty of Technology, Leskovac, Serbia

Wild cyclamen tubers (Cyclamen purpurascens Mill.) (Kukavica mountain, southeast Serbia) was used as an extraction material in this study. The aqueous extract has been obtained by reflux extraction at the boiling temperature with hydromodulus $1: 20 \mathrm{~m} / \mathrm{v}$ during 180 minutes. The identification of bioactive components in the extract was performed by using UHPLC-DAD-HESI-MS analysis. The concentrations of macro- and microelements in the extract were determined by Inductively Coupled Plasma-Optical Emission Spectrometry (ICP-OES). Isocyclamin and desglucocyclamin I were identified in the obtained extract. Potassium was in the highest concentration - $10241.65 \mathrm{mg} / \mathrm{kg}$ of the plant material, while zinc was present in the highest concentration (11.57 mg/kg of plant material) among heavy metals. Presented results have shown that the obtained extract from wild cyclamen tubers is a potential source of triterpenoide saponin components isocyclamin and desglucocyclamin I, as well as macro- and microelements.
(ORIGINAL SCIENTIFIC PAPER) UDC 582.689.1:66.061.34:543.5

Keywords: Wild cyclamen tubers, Aqueous extract, UHPLC-DAD-HESI-MS analysis, Micro- and Macroelements.

\section{Introduction}

Wild cyclamen (Cyclamen purpurascens Mill.; Syn. Cyclamen europaeum L.), or purple cyclamen, is a species in the Cyclamen genus of the Primulaceae family [1]. The Cyclamen L. (Primulaceae) genus is present in 20 wild and cultivated species in Europe [1,2].

Many plant extracts represent a source of secondary metabolites with different biological and pharmacological properties, and play a therapeutic role in the human organism [1]. According to traditional medicine, some species from the Cyclamen genus were used because of their biological activities [1,2] such as: cytotoxic, spermicidal, antimicrobial [1], laxative, abortive, sedative, purgative, emmenagogue and anti-helmintic [2]. Analgesic, anti-inflammatory, antimicrobial and antioxidative activities of some Cyclamen species such as Cyclamen repandum, Cyclamen mirabile and Cyclamen graecum have also been reported [1,3-6].

Investigating the chemical composition of several Cyclamen species, some authors have reported the presence of triterpene saponins and glycosides [4], phenolic components [7,8], anthocyanin and flavonoids [9]. Triterpenoid saponin components, which are highly valuable bioactive components, were early isolated from different Cyclamen species $[4,10-12]$. These saponins, structurally defined as triterpenes glycosides, are widespread components with multifarious chemical structures and biological activities such as antimicrobial, antiviral and antifungal. It has also been proven that triterpenoid saponins act as potent suppressors of various human cancer cell lines proliferation, including lung, stomach, colon, breast and liver cancer [13].
Besides the main bioactive components identification, macro- and microelements in the aqueous extract of wild cyclamen tubers have been determined having in mind that the consumption of plant isolates is increased because of their usage in mineral elements compensation. The phytochemical composition and the mineral content of the aqueous extract from wild cyclamen tubers grown in southeast Serbia were not published in the available literature. Taking into account the pharmacological significance of triterpenoid steroids, the chemical composition of species from the Cyclemen genus and wide spreading of the wild cyclamen in southeast Serbia, the aim of this paper was to isolate the aqueous extract from wild cyclamen tubers, determine bioactive components and the mineral elements content.

\section{Experimental}

\section{Reagents and chemicals}

Acetonitrile and water were purchased from Fisher Chemical (LC-MS and HPLC grade, respectively). Formic acid was purchased from Carlo Erba (France).

\section{Plant material}

Cyclamen tubers (fresh plant material) (Cyclamen purpurascens Mill.) (Kukavica mountain, southeast Serbia) was used for the extraction in this study. The plant material was milled in a laboratory disintegrator (a laboratory electric mill "BRAUNAROMATIC KSM2"), immediately before the extraction (the average diameter of the plant-solid material was $0.5 \mathrm{~mm}$ ).

\footnotetext{
*Author address: Ljiljana Stanojević, Faculty of Technology, Leskovac, University of Niš,

Bulevar Oslobodjenja 124, 16000 Leskovac, Serbia

E-mail: stanojevic@tf.ni.ac.rs

The manuscript received: November, 30, 2017.

Paper accepted: March, 7, 2018.
} 


\section{Reflux extraction}

The plant material $(15 \mathrm{~g})$ was extracted by reflux extraction with $300 \mathrm{ml}$ water (hydromodule, 1:20 m/v) at the boiling point. The extraction was performed for 180 minutes [14]. The extract was separated by filtering under a weak vacuum, and the solvent was removed by evaporation at $50{ }^{\circ} \mathrm{C}$. The obtained extract was dried in the vacuum dryer at $40{ }^{\circ} \mathrm{C}$ till constant mass and the content of total extractive matter (TEM, dry extract) was calculated on the basis of the dry residue content. TEM-value were expressed in $\mathrm{g} / 100 \mathrm{~g}$ of the fresh plant material.

\section{Determination of the plant extract yield}

The yield of the dried extract (TEM) was calculated from the equation 1 :

$\operatorname{TEM}(\mathrm{g} / 100 \mathrm{~g}$ of plant material $)=(\mathrm{W} 1 \times 100) / \mathrm{W} 2 \ldots \ldots . .(1)$ where: W1 is the weight of the extract after the solvent evaporation; W2 is the weight of the fresh plant material.

Ultrahigh performance liquid chromatography-diode array detection-mass spectrometry method (UHPLC-DADMS method)

Thermo Scientific liquid chromatography system (UHPLC) containing a diode array detector connected to LCQ Fleet Ion Trap Mass Spectrometer (Thermo Fisher Scientific, San Jose, California, USA) equipped with heated electrospray ionization (HESI) has been used for chromatographic separation. Hypersil gold C18 column $(50 \times 2.1$ $\mathrm{mm}, 1.9 \mu \mathrm{m}$ ) obtained from Thermo Fisher Scientific, in combination with Xcalibur (version 2.2 SP1.48) and LCQ Fleet (version 2.7.0.1103 SP1) software were used for separation, instrument control and data analysis.

UHPLC-DAD-HESI-MS/MS analysis was performed under isocratic conditions at the flow rate $0.2 \mathrm{ml} / \mathrm{min}$. The mobile phase consisted of water $+0.2 \%$ formic acid $(A)$, methanol (B) and acetonitrile (C), in the content of 5,85 and $10 \%$, respectively. The volume of $5 \mu$ was injected, while the column temperature has been maintained at $25^{\circ} \mathrm{C}$. The monitoring wavelengths were $\lambda_{\text {mon }}=300,350$, 400 and $450 \mathrm{~nm}$, and online spectra were recorded in the range of 200-800 nm. Positive mode was used in mass spectrometer operating; HESI-source parameters: source voltage $4.5 \mathrm{kV}$, capillary voltage $36 \mathrm{~V}$, tube lens voltage $110.00 \mathrm{~V}$, capillary temperature $275^{\circ} \mathrm{C}$, sheath and auxiliary gas flow $\left(\mathrm{N}_{2}\right) 50$ and 8 (arbitrary units), respectively. Full range acquisition covering 100-1000 m/z were used for MS-spectra acquiring. Data dependent scan was used by deploying the collision-induced dissociation (CID) for the fragmentation study. The normalized collision energy of the CID cell was set at $25 \mathrm{eV}$. Spectral characteristics (DAD, mass spectra, the accurate mass and characteristic fragmentation) have been used for all compounds identification.

\section{ICP-OES analysis of extract}

The extract of cyclamen tubers (in concentration of 5.0 $\mathrm{mg} / \mathrm{cm}^{3}$ ) was subjected to the ICP-OES analysis after wet digestion, i.e. $1 \mathrm{~cm}^{3}$ of the extract has been mixed with $1 \mathrm{~cm}^{3}$ of conc. $\mathrm{HNO}_{3}$. The obtained mixture, after wet digestion, was diluted with water purified by Fisher Chemical (HPLC grade) to volume of $10 \mathrm{~cm}^{3}$ and filtered $(0.45 \mu \mathrm{m})$ before the ICP-OES analysis.

The ICP-OES (Inductively Coupled Plasma - Optical Emission Spectrometry, ARCOS FHE12, SPECTRO, Germany) has been used for the quantitative analysis of the samples. The analysis was performed according to the manufacturer's instructions. The instrument conditions and determined parameters are given in Table 1.

Table 1. Operating conditions for ICP-OES analysis

\begin{tabular}{cc}
\hline Plasma Power (W) & 1400 \\
Gas flow $\left(\mathrm{dm}^{3} / \mathrm{min}\right)$ & 12 \\
-Coolant & 1.0 \\
-Auxiliary & Cross flow \\
Nebulizer type & 1.0 \\
Nebulizer flow rate (dm $\left.{ }^{3} / \mathrm{min}\right)$ & 30 \\
Pump speed & 0 \\
Stabilization time (s) & 3 \\
Number of probes for each measuring & axial \\
\hline
\end{tabular}

The analyzed elements were divided into two groups: macroelements ( $\mathrm{K}, \mathrm{Ca}, \mathrm{Mg}$ and $\mathrm{Na}$ ) and microelements (Fe, Mn, $\mathrm{Cr}, \mathrm{Cu}, \mathrm{Ni}$ and $\mathrm{Zn}$ ). The carrier gas was argon 5.0 (99.999\% purity). Multistandard IV (Merck), containing $\mathrm{Ca}, \mathrm{Cr}, \mathrm{Cu}, \mathrm{Fe}, \mathrm{K}, \mathrm{Mg}, \mathrm{Mn}, \mathrm{Na}, \mathrm{Ni}$ and $\mathrm{Zn}$ in the concentration of $1000 \mathrm{ppm}$, have been prepared for calibration. Standard solutions have been diluted for the calibration curve construction, in the range of expected elements concentrations.

\section{Results and discussion}

The yield of the evaporated dried extract was $10.0 \mathrm{~g} / 100 \mathrm{~g}$ of the plant material. The typical UHPLC-DAD chromatogram of the cyclamen tubers aqueous extract recorded at $\lambda$ mon $=400 \mathrm{~nm}$ (as representative chromatogram) was shown in Figure 1. The list of MS-spectral characteristics of identified compounds from the extract (labeled as peaks 1 and 2, following the elution orders in the UHPLCDAD chromatograms), are shown in Table 2. If we take into account the peak area, it could be concluded that the presence of desglucocyclamin I (70811 mAUs) is two times higher than isocyclamin (36283 mAUs). The structures of both identified compounds are shown in Figure 2. 


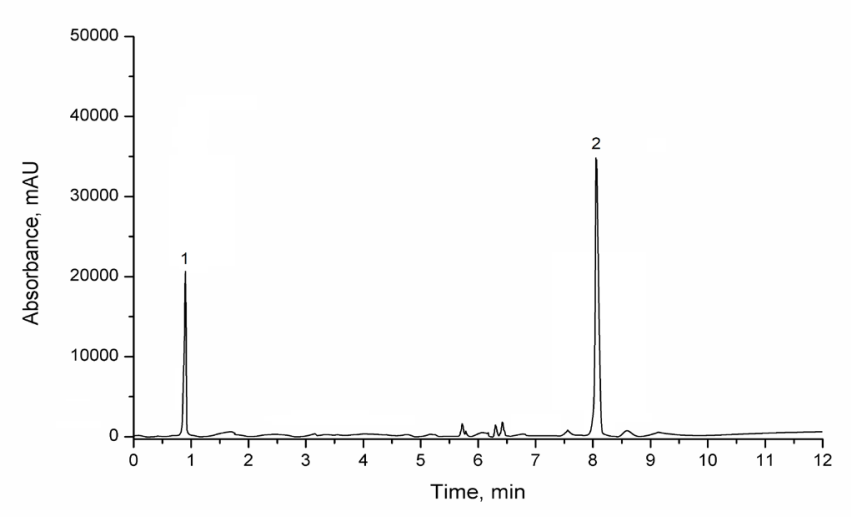

Figure 1. UHPLC chromatogram of the wild cyclamen tubers aqueous extract recorded at $400 \mathrm{~nm}$

Table 2. Identified components of the wild cyclamen tubers extract

\begin{tabular}{ccccc}
\hline $\begin{array}{c}\text { Peak, } \\
\text { no. }\end{array}$ & $\boldsymbol{t}_{\mathrm{R}}, \mathbf{m i n}$ & $\mathbf{m} / \mathbf{z}[\mathrm{M}+\mathrm{H}]^{+}$ & $\mathbf{M S} / \mathrm{MS}$ & Compound \\
\hline & & & 1060.21 & \\
& & & 751.07 & \\
1 & 0.88 & 1222.14 & 471.47 & Isocyclamin \\
& & & 453.06 & \\
& & & 337.05 & \\
& & & 325.17 & \\
2 & 8.11 & 1083.05 & 950.36 & \\
& & {$[\mathrm{M}+\mathrm{Na}]^{+}$} & 628.41 & Desglucocyclamin I \\
\hline
\end{tabular}

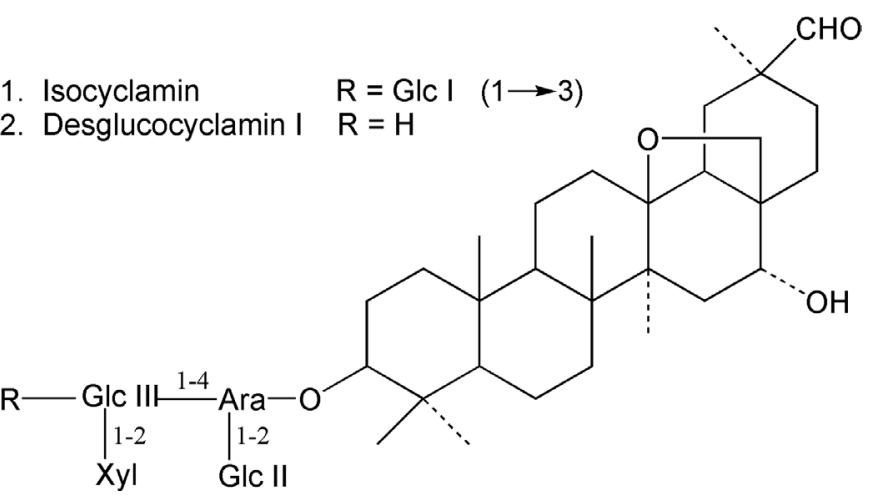

Figure 2. The structures of isocyclamin and desglucocyclamin I

The first peak was identified as isocyclamin at retention time $0.88 \mathrm{~min}$ (Figure 1). After MS/MS fragmentation of molecular ion at $\mathrm{m} / \mathrm{z} 1222.14[\mathrm{M}+\mathrm{H}]^{+}$there were several fragment ions at $\mathrm{m} / \mathrm{z} 1060.21[\mathrm{M}-\mathrm{Glucose} \mathrm{II}+2 \mathrm{H}]^{+}$, 751.07 [M-Aglycone-H] $]^{+}, 471.47$ [M-sugar moiety+2 $]^{+}$, 453.06 [M-sugar moiety- $\left.\mathrm{H}_{2} \mathrm{O}+2 \mathrm{H}\right]^{+}, 437.05$ [M-sugar moiety- $\left.-\mathrm{H}_{2} \mathrm{O}+2 \mathrm{H}\right]^{+}$and 325.17 [Glc II+Glucose I] ${ }^{+}$(Figure 2 (structure 1), Table 2). The results are in agreement with the ones previously published by Yayli and coworkers [12]. The second peak $\left(t_{R}=8.11 \mathrm{~min}\right.$, Figure 1) was identified as desglucocyclamin I (Figure 2, structure 2). Based on cationized molecular ion at $\mathrm{m} / \mathrm{z}$ $1083.05[\mathrm{M}+\mathrm{Na}]^{+}$and its fragment ions at $\mathrm{m} / \mathrm{z} 950.36$, $628.41,497.08$ it can be concluded that second peak
(Figure 1) represents desglucocyclamin I [6]. The presence of desglucocyclamin I was detected by Waltho and coworkers (1986) where the subject of the investigation was Androsace saxifragijblia (gen. Cyclamen) [15]. In the study of Jansakul and coworkers (1986), this saponin has been isolated from Ardisia crispa, but under the name of ardisiacrispin A [16].

Triterpene saponins were identified from Cyclamen coum var. coum [10] and from C. hederifolium [2]. The presence of triterpene saponins cyclamin and desglucociclamin I in the $C$. trocopteranthum tubers methanolic extract was reported by Mihci-Gaidi and coworkers [17]. Calis et al. also reported the presence of these components in the methanolic extract of $C$. mirabile Hildebr., an endemic species growing in Turkey [4]. Petroleum ether, chloroform and the methanol extract of $C$. repandum tubers from Italy showed a significant anti-inflammatory and analgesic activity which can be attributed to triterpenoid saponins [1]. According to the results obtained in this work, it can be noticed that saponins are present in all investigated types of cyclamen. The number of these compounds, as well as their content in the extracts, depends both on the solvent used and on the cyclamen species $[1,2,4,10,17]$. Two saponins (isocyclamin and desglucocyclamin I) were identified in the aqueous extract isolated from wild cyclamen. A significantly higher number of saponins were extracted with methanol from Cyclamen repandum [1] and Cyclamen mirabile [4] tubers. Petrol ether and chloroform extracts from Cyclamen repandum tubers contain a significantly smaller amount of saponins than the methanol extract [1].

Most of triterpenoid saponins exert antitumor effects [13] such as the antiproliferative activity on different cancer cell lines including Hela (human cervical cancer cells), H-446 (human lung cancer cells), HT-29 (human colon carcinoma cells), U937 (human leukemia cells) [2]. It should be emphasized that cyclamin and desglucocyclamin I exert a cytotoxic activity on two human colorectal cancer cells (HCT 116 and HT-29) [17]. Triterpenoid saponins containing a 13,28-epoxy moiety in the oleanane-type sapogenin structure (like cyclamen) exert a tumor selective cytotoxic action towards human liver cancer cells, but not affecting the normal liver cells viability [13]. Bearing in mind that wild cyclamen grows in southeast Serbia as a self-sown plant, such results can be important for its possible exploitation, i.e. the isolation of highly-valuable triterpenoid saponins identified in the aqueous extract, and their further application in phytopreparates.

Minerals are essential for the normal development of all metabolic functions, transmission of nerve impulses, bone formation, water and salt balance regulation [18]. The increased minerals content, as well as their deficiency in the body, can lead to various disorders [19]. After digestion, ten elements were analyzed in the wild cyclamen tubers aqueous extract using ICP-OES. The average concentrations of elements, expressed as mg/ $\mathrm{kg}$ (fresh plant material), the wavelength for each ele- 
ment in the samples, the correlation coefficient $\left(R^{2}\right)$, the limit of detection (LOD), as well as the linearity range are shown in Table 3. The analyzed elements were divided into two groups: macroelements ( $\mathrm{K}, \mathrm{Ca}, \mathrm{Mg}$ and $\mathrm{Na}$ ) and microelements ( $\mathrm{Zn}, \mathrm{Fe}, \mathrm{Mn}, \mathrm{Cu}, \mathrm{Cr}$ and $\mathrm{Ni})$.

Table 3. The mineral content (in $\mathrm{mg} / \mathrm{kg}$ plant material) of wild cyclamen tubers and calibration parameters for ICP-OES analysis (detection wavelength $(\lambda)$, correlation coefficient $\left(R^{2}\right)$, limit of detection and linearity range).

\begin{tabular}{|c|c|c|c|c|c|}
\hline Element & $\begin{array}{c}\text { Detection } \\
\text { wavelength } \\
(\lambda, \mathrm{nm})\end{array}$ & $\begin{array}{c}\text { Correlation } \\
\text { coefficient } \\
\left(\mathbf{R}^{2}\right)\end{array}$ & $\begin{array}{l}\text { Limit of } \\
\text { detection } \\
\left(\mu \mathrm{g} / \mathrm{dm}^{3}\right)\end{array}$ & $\begin{array}{c}\text { Linearity } \\
\text { range }\left(\mathrm{mg} / \mathrm{dm}^{3}\right)\end{array}$ & $\begin{array}{c}\text { Concentration } \\
\text { (mg/kg plant } \\
\text { material) }\end{array}$ \\
\hline \multicolumn{6}{|c|}{ Macroelements (K, Ca, Mg, Na) } \\
\hline \multirow{2}{*}{$\mathrm{Ca}$} & 183.801 & 0.99995 & \multirow{2}{*}{2.14} & $1.6-480.00$ & \multirow{2}{*}{312.67} \\
\hline & 396.847 & 0.99946 & & $0.00214-2.41$ & \\
\hline \multirow{2}{*}{$\mathrm{K}$} & 404.721 & 0.99998 & \multirow{2}{*}{0.378} & $0.798-300.00$ & \multirow{2}{*}{10241.65} \\
\hline & 766.491 & 0.99999 & & $0.000378-1.20$ & \\
\hline \multirow{2}{*}{$\mathrm{Mg}$} & 279.553 & 0.99997 & \multirow{2}{*}{0.115} & $0.000115-6.04$ & \multirow{2}{*}{1803.76} \\
\hline & 285.213 & 0.99994 & & $4.03-120.00$ & \\
\hline \multirow{2}{*}{$\mathrm{Na}$} & 330.237 & 0.99994 & \multirow{2}{*}{4.75} & $7.98-480.00$ & \multirow{2}{*}{532.75} \\
\hline & 598.592 & 0.99989 & & $0.00475-12.00$ & \\
\hline \multicolumn{6}{|c|}{ Microelements (Fe, Mn, $\mathrm{Cr}, \mathrm{Cu}, \mathrm{Ni}, \mathrm{Zn}$ ) } \\
\hline $\mathrm{Fe}$ & 259.941 & 0.99997 & 0.118 & $0.000118-12.00$ & 0.75 \\
\hline $\mathrm{Mn}$ & 257.611 & 0.99992 & $3.57 \times 10^{-2}$ & $3.57 \times 10^{-5}-12.00$ & 4.85 \\
\hline $\mathrm{Cr}$ & 283.563 & 0.99998 & 0.435 & $0.000435-12.00$ & 0.0 \\
\hline \multirow{2}{*}{$\mathrm{Cu}$} & 224.700 & 0.99999 & \multirow{2}{*}{0.259} & $0.000907-12.00$ & \multirow{2}{*}{4.48} \\
\hline & 324.754 & 0.99999 & & $0.000259-12.00$ & \\
\hline $\mathrm{Ni}$ & 231.604 & 0.99994 & 0.474 & $0.000474-12.00$ & 0.0 \\
\hline $\mathrm{Zn}$ & 213.856 & 0.99997 & $8.2 \times 10^{-2}$ & $8.2 \times 10^{-5}-12.00$ & 11.57 \\
\hline
\end{tabular}

Sodium, potassium, calcium and magnesium belong to the necessary macroelements. These minerals are necessary in relatively large quantities for normal functioning of physiological processes of the human organism. The major macroelement in the analyzed sample was $\mathrm{K}$ with the concentrations of $10241.65 \mathrm{~g} / \mathrm{kg}$ of cyclamen tubers (Table 3), followed by $\mathrm{Mg}, \mathrm{Na}$ and $\mathrm{Ca}$.

Potassium is a macroelement necessary for many metabolic processes, primarily for the acid-base balance and osmotic pressure maintenance in the organism (as an electrolyte), as well as for normal brain, heart, kidneys and muscles functioning [20]. Due to lack of potassium, various disorders can occur such as fatigue, muscle weakness, hypertension, cardiac arrhythmias, anemia, severe headaches [20]. Besides potassium, sodium is a necessary element for the nerve impulses transmission, muscle tonus maintenance and membrane permeability. Lack of sodium leads to the blood pressure reduction, general weakness of the organism and loss of appetite [20].

Calcium is a mineral that is also essential in the body. Lack of this element causes rachitis in children, leading to osteomalacia and osteoporosis in adults [21].

It is also important that the extract contains a high content of $\mathrm{Mg}(1.8 \mathrm{~g} / \mathrm{kg}$ of plant material). Magnesium regulates the energy production in the cells, metabolism and function of more than 300 different enzymes. In addition, Mg protects the heart and blood vessels, reduces the level of fat in the blood and is necessary for the func- tioning of muscles and nerves. Due to the lack of Mg, there are various disorders such as spasms, pre-fatigue, arrhythmia, and even infarct myocardium [22]. Together with $\mathrm{Ca}, \mathrm{Mg}$ acts as a natural calming agent [23]. A high level of $\mathrm{K}$ and $\mathrm{Mg}$ in the extract probably comes from the high content of these minerals in the soil [24] which leads to the conclusion that the aqueous extract of wild cyclamen is a source of macroelements, especially $\mathrm{Mg}$, necessary for the normal functioning of many enzymes and biochemical processes occurring [22].

Microelements, as an integral part of enzymes or proteins, have an important biological role in human organism in terms of the proper enzymes functioning. Also, some of trace elements have an important role in biochemical processes. Iron, manganese, zinc and copper are microelements of particular importance. The major microelement found in the analyzed extract was $\mathrm{Zn}$ (Table 3) with the mean concentration of $11.57 \mathrm{mg} / \mathrm{kg}$, followed by $\mathrm{Mn}, \mathrm{Cu}$ and $\mathrm{Fe}$. The presence of $\mathrm{Cr}$ and $\mathrm{Ni}$ was not detected in the wild cyclamen tubers extract, i.e. their content in the sample was below the detection limit. The obtained minerals content (Table 3 ) is probably a result of the soil composition where the cyclamen has been grown, having in mind that soil is the main metal source for plants [24]. A different concentration of minerals in the plant and their bioavailability can also depend on the geographical origin and the environmental pollution [19].

The adequate combination of minerals, vitamins and sugars are necessary for the normal skin functioning. The results obtained by ICP-OAS analysis, especially the presence of copper and zinc, suggest that the aqueous extract from wild cyclamen tubers represents a natural source of these elements with the potential external application and treatment of various changes in the skin.

\section{Conclusion}

According to the results obtained, it can be concluded that two components are identified in the aqueous extract of wild cyclamen tubers grown in southeast Serbia: isocyclamine and desglucocyclamine I. Having in mind the importance of the identified components in terms of pharmacological activity, further research will be focused on the isolation of these components and the determination of their biological activities in vitro. Eight minerals have been identified in the extract, whereby $\mathrm{K}$ is the main macroelement and $\mathrm{Zn}$ as the main microelement. The high content of macroelements in the extract, especially $\mathrm{K}$ and $\mathrm{Mg}$, candidates the cyclamen extract as suitable for daily needs of these minerals compensation. The results show that the obtained extract represents a promising raw material for the isolation of highly valuable bioactive components isocyclamine and desglucocyclamine I, with their potential application in pharmaceutical industry and the analyzed extract is a potential source of some dietary metals such as $\mathrm{K}, \mathrm{Mg}, \mathrm{Ca}, \mathrm{Na}$ and $\mathrm{Zn}$. 


\section{Acknowledgements}

This work was supported under the Project on Development of Technology number TR-34012 by the Ministry of Education, Science and Technological Development of the Republic of Serbia.

\section{References}

[1] E. Speroni, R. Cervellati, S. Costa, S. Dall'Acqua, M.C. Guerra, C. Panizzolo, A. Utan, G. Innocenti, Analgesic and antiinflammatory activity of Cyclamen repandum S. et S. Phytotherapy Research, 21 (2007) 684-689.

[2] H. Altunkeyik, D. Gülcemal, M. Masullo, O. AlankusCaliskan, S. Piacente, T. Karayildirima, Triterpene saponins from Cyclamen hederifolium, Phytochemistry, 73 (2012) 127-133.

[3] S. Dall'Acqua, I. Castagliuolo, P.Brun, F. Ditadi,G.Palù, G. Innocenti, Triterpene glycosides with in vitro antiinflammatory activity from Cyclamen repandum tubers, Carbohydrate Research, 345 (2010) 709-714.

[4] T.Caliş, M.E. Satana, A. Yürüker, P. Kelican, R. Demirdamar, R. Alaçam, N. Tanker, H. Rüegger, O. Sticher, Triterpene saponins from Cyclamen mirabile and their biological activities, Journal of Natural Products, 60 (1997) 315-318.

[5] G. Okmen, P. Erdal, D. Isik, D. Bayrak, The antibacterial activities against mastitis pathogens of Cyclamen mirabile Hildebr. tubers and its non-enzymatic antioxidant activities, European Journal of Experimental Biology, 4(2) (2014) 370-374.

[6] C. Lavaud, G. Massiot, J.B. Barrera, C. Moretti, L.L. Men-Olivier, Triterpene saponins from Myrsine pellucida, Phytochemistry, 37 (1994) 1671-1677.

[7] H. Metın, C. Aydın, C. Ozay, R. Mammadov, Antioxidant Activity of the Various Extracts of Cyclamen graecum Link Tubers and Leaves from Turkey, Journal of The Chemical Society Of Pakistan, 35(5) (2013) 1332-1336.

[8] C. Sarikurkcu, Antioxidant activities of solvent extracts from endemic Cyclamen mirabile Hildebr. tubers and leaves, African Journal of Biotechnology, 10(5) (2011) 831-839.

[9] R.F. Webby, M.R. Boase, Peonidin3-O-neohesperidoside and other flavonoids from Cyclamen persicum petals, Phytochemistry, 52 (1999) 939-941.

[10] I. Calis, A. Yuruker, N. Tanker, A.D. Wright, O. Sticher, Triterpene saponins from Cyclamen coum var. coum., Planta Medica, 63 (1997) 166-170.

[11] N. Yayli, C. Baltaci, A. Zengin, M. Kucukislamoglu, H. Genc, M. Kucuk, A triterpenoid saponin from Cyclamen coum. Phytochemistry, 48 (1998) 881-884.

[12] N. Yayli, C. Baltaci, A. Zengin, M. Kucukislamoglu, H. Genc, M. Kucuk, Pentacyclic triterpenoid saponin from Cyclamen coum. Planta Medica, 64 (1998) 382-384.

[13] Q. Li, L. Deng, W. Li, K. Koike, Cyclamin, a Natural 13,28-Epoxy Triterpenoid Saponin, Synergistically Enhances the Cytotoxicity of Chemotherapeutic Drugs in Human Liver Cancer Cells but Not Non-Neoplastic Liver Cells, Planta Medica, 80 (2014) 409-414.

[14] Lj.P. Stanojević, M.Z. Stanković, A. Juma, Antioxidant activity of aqueous extracts from dill fruit (Anethi fructus) obtained by different extraction techniques, Advanced technologies, 5(2) (2016) 46-52.
[15] J.P. Waltho, D.H. Williams, S.B. Mahato, B.C. PaL, J.C.J. Barnaa, Structure Elucidation of Two Triterpenoid Tetrasaccharides from Androsace saxifragifolia , Journal of the Chemical Society, Perkin Transactions 1, 0 (1986) 1527-1531.

[16] C. Jansakul, H. Baumann, L. Kenne, G. Samuelsson, Ardisiacrispin $A$ and $B$, two utero-contracting saponins from Ardisia crispa, Planta Medica, 53(5) (1987) 405-409.

[17] G. Mihci-Gaidi, S. Ozbey, I. Orhan, B. Sener, T. Miyamoto, J.-F. Mirjolet, O. Duchamp, A.-C. Mitaine-Offer, M.-A. Lacaille-Dubois, Triterpene Saponins from Cyclamen trocopteranthum, Planta Medica, 76 (2010) 818-821.

[18] P. Kalac, L. Svoboda, A review of trace elements concentration in edible mushrooms, Food Chemistry, 69, (2000) 273-281.

[19] L. Queralt, M. Ovejero, M.L. Carvalho, A.F. Marques, J.M. Llabres, Quantitative determination of essential and trace element content of medicinal plants and their infusions by XRF and ICP techniques. X-Ray Spectrometry, 34 (2005) 213-217.

[20] D. Veljković, G. N. Vučković, Minerali u ishrani, Hemijski pregled, 51 (2010) $14-19$.

[21] J.N. Hathcock, Vitamin and Mineral Safety, in Council for Responsible Nutrition, 2nd Edition, CRN Press, Washington, 2004.

[22] M.E. Shils, Magnesium, in Moderan nutrition in health and diease, M. E. Shils, J. A. Olson, M. Shike, C. A. Ross, 9th Edition, Wiliams \& Wilkins, Philadelphia, 1999, pp. $169-192$.

[23] A. Ascherio, E. B. Rimm, M. A. Hernana, E. L. Giovannucci, I. Kawachi, M. J. Stampfer, W. C. Willett, Intake of Potassium, Magnesium, Calcium, and Fiber and Risk of Stroke Among US Men, Circulation, 98 (1998) 1198-1204.

[24] D. Velimirović, Optimizacija, validacija i primena ICP-OES metode određivanja sadržaja metala u realnim uzorcima, Doktorska disertacija, PMF, Univerzitet u Nišu, 2013. 
Izvod

\section{BIOAKTIVNE KOMPONENTE I MINERALNI SASTAV VODENOG EKSTRAKTA KRTOLE DIVLJE CIKLAME (Cyclamen purpurascens Mill.)}

Ljiljana Stanojević, Dragan Cvetković, Saša Savić, Sanja Petrović, Milorad Cakić

Univerzitet u Nišu, Tehnološki fakultet Leskovac, Srbija

Krtola divlje ciklame (Ciclamen purpurascens Mill.) (Planina Kukavica, jugoistočna Srbija) korišćena je kao materijal za ekstrakciju u ovoj studiji. Vodeni ekstrakt je dobijen ekstrakcijom uz refluks na temperaturi ključanja pri hidromodulu 1:20 m/v tokom 180 minuta. Identifikacija bioaktivnih komponenti u ekstraktu izvršena je UHPLC-DAD-HESI-MS analizom. Koncentracije makro- i mikro elemenata u ekstraktu određene su primenom optičke emisione spektometrije sa indukovano spregnutom plazmom (ICP-OES). U dobijenom ekstraktu identifikovane su komponente izociklamin i desglukociklamin I. Koncentracija kalijuma bila je najviša - 10241,65 mg/kg biljnog materijala. Najzastupljeniji teški metal bio je cink u količini od $11,57 \mathrm{mg} / \mathrm{kg}$ biljnog materijala. Prikazani rezultati pokazuju da je vodeni ekstrakt krtole divlje ciklame potencijalni izvor triterpenoidnih soponina izociklamina i desglukociklamina I, kao i makro- i mikroelementa.
(ORIGINALNI NAUČNI RAD) UDK 582.689.1:66.061.34:543.5

Ključne reči: Krtola divlje ciklame, Vodeni ekstrakt, UHPLC-DAD-HESI-MS analiza, Mikro- i makroelementi. 